\title{
OS CLÁSSICOS NAS NOITES: ESTUDO COMPARATIVO ENTRE PENÉLOPE E ŠAHRĀZĀD
}

\section{THE CLASSICS IN THE NIGHTS: COMPARATIVE STUDY BETWEEN PENELOPE AND ŠAHRĀZĀD}

\author{
Letícia Gabriela de Castro Monteiro*
}

\begin{abstract}
Resumo: Ainda que a repercussão da cultura grega do Livro das Mil e Uma Noites não receba tanta atenção como a indiana ou bíblica, é fato que ela existe e pode ser verificada no decorrer da obra. Dentre estas contribuições, encontram-se poemas clássicos tais como a Ilíada e a Odisseia de Homero. Assim, esta pesquisa se propõe a discutir semelhanças entre a personagens Penélope e Šahrāzād. Desta maneira, tenta-se descobrir quais significados surgem em decorrência da presença de Penélope em Šahrāzād, a partir das noções de intertextualidade por Fowler (1997), de modo a compreender os impactos culturais deixados por Homero no Islã medieval. Da mesma forma, pretende-se verificar como as personagens citadas colaboram para a visão da sexualidade feminina na Antiguidade e na Idade Média.
\end{abstract}

Palavras-chave: Penélope. Šahrāzād. Intertextualidade.

\begin{abstract}
Although the repercussion of the Greek culture of the Arabian Nights does not receive as much attention as the Indian or biblical, it exists and it can be found through in the book. Among these contributions, we can mention classic poems such as Iliad and Homer's Odyssey. Thus, this research offers similarities between the female characters Penelope and Šahrāzād. In this way, this research attempts to discover what meanings arise as a result of Penelope's presence in Šahrāzād, based on the notions of the concepts by Fowler (1997), in order to understand the cultural acts left by Homer in medieval Islam. In the same way, it is intended to verify how the characters mentioned collaborate for the vision of female sexuality in Antiquity and the Middle Ages.
\end{abstract}

Keywords: Penelope. Šahrāzād. Intertextuality.

\footnotetext{
${ }^{*}$ Bacharel em Letras pela FFLCH/USP. Email: <legabi.monteiro@gmail.com>.
} 


\section{INTRODUÇÃO'}

O Livro das Mil e Uma Noites é conhecido pelos estudiosos como uma obra fruto da herança de várias culturas. Nele, encontram-se vestígios indianos, persas, egípcios, babilônicos, dentre vários outros, incluindo os gregos. Este último, em especial sofreu dificuldades para chegar até as terras árabes. Os gregos não compartilharam da mesma estrutura narrativa, como o caso do quadro-conto, muito utilizado na Índia, e os aspectos culturais - sobretudo os religiosos - apresentavam diferenças muito significativas e difíceis de se traduzir. Assim, as histórias importadas da Grécia sofreram grandes modificações para se adequar ao estilo das Noites (GRUNEBAUM, 1942, p. 277-278). Não obstante, é fato que, apesar de Homero ser conhecido por sua influência na cultura ocidental, também teve importância para o oriente: "mesmo uma investigação superficial das traduções homéricas publicadas no século XX mostra que Homero foi considerado relevante para leitores de ucraniano, árabe, chinês, esperanto, albanês, turco e coreano" (GRAZIOZI; GREENWOOD, 2007, p.1). ${ }^{2}$ Antes disto, entretanto, não houve traduções homéricas para o árabe, dificultando seu intercâmbio entre o Islã clássico. Todavia, segundo Irwin (2004, p. 71), sabemos que certos estudiosos árabes da época tinham conhecimento da poesia de Homero, como o tradutor Hunayn ibn Ishaq, portanto, não é impossível encontrar diálogos entre as obras. Por exemplo, a rainha Lāb - do conto Jullānar, a marítima, e seu filho Badr - e a feiticeira Circe são mulheres sensuais e libidinosas que transformam homens em animais. A própria Jullānar também pode ser comparada a outra divindade homérica: Tétis - mãe de Aquiles -, também uma deidade aquática e maternal. Além desses casos, pode-se citar Odisseu e Sindabād, os quais, além de atravessarem o oceano em um perigoso universo fantástico, vivem um episódio bastante similar, em que enfrentam um gigante e derrotam-no ao cegá-lo (IRWIN, 2004, p. 71).

Desta forma, é possível perceber que houve, senão uma influência direta, ao menos uma interação entre as obras homéricas e as Noites. Portanto, não seria incoerente aproximar outras figuras destas duas obras, no caso, Penélope e Šahrāzād. A análise dos ecos encontrados entre as personagens se sustenta para além da comparação em si: ela traz consigo a discussão sobre a visão da confiança depositada nas mulheres na Antiguidade e na Idade Média - e como, apesar dos vários séculos de diferença, pouca coisa mudou.

\footnotetext{
${ }^{1}$ Este artigo se baseia no TGI da autora. Desse modo, a metodologia e os argumentos utilizados para retratar Penélope seguem princípios semelhantes, com aprimoramento relevante.

2 "Even a superficial survey of Homeric translations published in the twentleth century shows that Homer was deemed relevant to readers of, to quote but a few, Ultramian, Arabic, Chinese, Esperanto, Albanian, Turkish, and Korean".
} 
Mesmo em diferentes culturas e épocas, em geral, o imaginário masculino tende a conceber a mulher como detentora do mal. Os exemplos mais famosos são Pandora e Eva, advindas da mitologia grega e bíblica respectivamente: apesar de algumas disparidades, ambas são representadas não somente como A Primeira Mulher, mas como motivo para a humanidade viver em desgraça. Pandora teria sido feita como punição aos homens - que receberam, contra a vontade de Zeus, o fogo como presente de Prometeu - e viria carregando um jarro cujo conteúdo seria todos os males que hoje assombram a Terra. Eva, por outro lado, foi um presente de Deus para Adão, para lhe fazer companhia. Contudo, foi Eva a responsável por comer do fruto proibido e convencer Adão a fazê-lo também, o que os levaria à expulsão do paraíso, sendo condenados ao mundo de horrores em que hoje vivemos. Deste modo, de acordo com Glenn (1997), estas histórias expõem não somente os motivos pelos quais os homens não deveriam confiar nas mulheres, mas também a periculosidade da sexualidade feminina: afinal, tanto o jarro quanto o fruto seriam o símbolo da libido e da fertilidade da mulher.

Os exemplos não terminam com os contos sobre a primeira mulher. Casos famosos na literatura e na mitologia demonstram um mundo onde a sexualidade feminina é motivo de grandes conflitos, mortes e incontáveis sofrimentos. À exemplo de Homero, pode-se citar Helena, cuja terrível beleza e sensualidade foi causa de uma das maiores guerras conhecidas pelos gregos. Outro exemplo é Clitemnestra, irmã de Helena e esposa do líder dos aqueus, Agamêmnon, que não apenas traiu seu marido como o matou, com ajuda do amante. Além disto, o universo da Odisseia é cercado de figuras femininas cuja libido e sensualidade são tão fortes quanto seu poder de destruição. O Livro das Mil e Uma Noites não foge à regra: o próprio prólogo-moldura é marcado pela traição que o rei Sāhriyār e seu irmão sofrem, e pelo episódio em que ambos são obrigados a possuir a esposa de um gênio (ou ifrit, de acordo com a tradução de Jarouche, 2018). Deste modo, não são incomuns passagens como: "nada é confiável entre as mulheres" $(O d .11,456)$ ou "nunca se está a salvo das artimanhas femininas" (LIVRO, 2018a, p. 337).

Contudo, Penélope e Šahrāzād surgem como figuras que pretendem provar que nem todas as mulheres são traiçoeiras. Inteligentes e ardilosas, através de seus estratagemas, conseguem controlar ou até destruir o caos que as rodeia. Penélope governa o reino de Ítaca enquanto seu marido, Odisseu, está fora e, mesmo sendo constantemente assediada por pretendentes que ameaçam a riqueza de seu esposo, consegue mantê-los distraídos e até mesmo arrancar-lhes presentes para que as finanças do marido não ficassem debilitadas. Šahrāzād, por sua vez, consegue convencer seu marido, Sāhriyār, a preservar sua vida e, consequentemente, não matar mais nenhuma mulher do reino. Não obstante, a verdadeira causa da fama destas 
personagens é a fidelidade: ainda que inseridas em um cenário em que as mulheres eram inevitavelmente traidoras e perigosamente sedutoras, Penélope não se entregou a nenhum de seus pretendentes, enquanto Šahrāzād manteve-se fiel a Sāhriyār durante mil e uma noites. Penélope e Šahrāzād, portanto, representam a exceção: a mulher confiável, a mulher fiel, a mulher que, mesmo sendo fêmea, é virtuosa. Inevitavelmente, deparamos com o que significa a virtude feminina em uma sociedade patriarcal, assunto sobre o qual também pretendemos detalhar neste trabalho.

Para tanto, utilizaremos a noção de intertextualidade apresentada por Fowler (1997). De acordo com o autor, nenhum texto se apresenta de forma isolada, mas através do que ele chama de sistema literário, ferramenta fundamental que imprime significado à obra (p.14). Em outros termos: intencionalmente ou não, todos os textos estão fadados a repetir e dialogar com outros. Mesmo que haja a tentativa de se desvencilhar de textos antecessores, a interação intertextual ainda poderá ser rastreada através da lacuna deixada. Assim, a intertextualidade é uma característica pública do texto e independe da intenção original do autor.

É importante relembrar que o sistema literário em que a relação intertextual se baseia não é único e fixo: ele é construído a partir do processo de leitura, ou seja, a recepção. E esta, por sua vez, é influenciada por diversos fatores que vão desde aspectos socioculturais até a experiência individual de cada leitor. Deste modo, "dizer que este texto é relevante, mas não esse texto, não é descobrir o sistema literário, mas construí-lo (...)” (FOWLER, 1996, p. 25). Portanto, traçar as características intertextuais de uma obra sempre é, em última análise, uma atitude arbitrária. É impossível diferenciar o que há de referência e o que há de original, e todas as tentativas são sempre ideológicas. Nesse sentido, o importante para a análise comparativa, segundo Fowler (1996, p. 19-20), é a nitidez da correspondência proposta entre os textos e o significado que ela lhes atribui. Para falar de outro modo, todo texto pode ser comparado a algum outro texto - e o que vai fazer com que tal comparação tenha peso é o quão nítida consegue ser a intertextualidade entre as obras, e o que ela acrescenta de significativo à interpretação de ambas.

Deste modo, a partir desta metodologia, pretendemos observar os ecos de Homero na famosa obra árabe e responder a algumas perguntas, tais quais: como seria uma leitura das Noites à luz de semelhanças com Odisseia? Como seria uma leitura da Odisseia à luz de semelhanças com as Noites? O que as semelhanças entre Šahrāzād e Penélope podem dizer sobre a visão em relação a mulheres no imaginário das culturas antigas e medievais? 


\section{PENÉLOPE}

A fiel e astuta esposa de Odisseu, Penélope, não é uma personagem fácil de ser decifrada. Isso se deve, sobretudo, ao fato de que sua "identidade [...], mais que a de qualquer outra personagem do poema, é construída através dos olhos e, sobretudo, dos relatos dos outros" (WERNER, 2014, p. 82). Ou seja, a rainha de Ítaca é concebida tanto como uma frágil e sofredora esposa, quanto uma mulher manipuladora e fria, dependendo de quem a descreve. Assim, com suas caracterizações turvas e ações contraditórias - como veremos mais adiante Penélope é, antes de tudo, uma personagem ambígua e, por este motivo, coleciona diversas opiniões de estudiosos. Esta ambiguidade, em um primeiro momento, sustenta-se em sua indefinida situação marital, uma vez que há anos não recebe notícias de seu marido. Diante de sua dupla condição de viúva e não-viúva, não é de se espantar que Penélope também se divida entre desistência e a esperança.

É fato que a excelência de Penélope enquanto a esposa ideal se decorre justamente de seu bem-sucedido esforço em manter a memória de Odisseu (CANEVARO, 2018, p.72). Como exemplo, citamos um episódio do primeiro canto do poema (vv. 336-44). Nesta passagem, Penélope repreende o adendo pois ele “(...) não deve estar cantando uma história que contenha o fim de Odisseu, já que o herói, de acordo com a perspectiva em Ítaca no presente, como já informado ao receptor, tem destino desconhecido" (WERNER, 2018, p. 98). A rainha não está tão somente preocupada com a dolorosa saudade que a lembrança do marido pode causar nela mesma, mas com os efeitos que uma canção pessimista sobre Odisseu pode causar aos habitantes de Ítaca. Penélope compreende que preservar a memória do marido e manter a esperança previne que a ausência do herói seja consolidada. A rainha, então, propõe uma mudança ao canto: pede a Fêmio que narre os grandes feitos de Odisseu, aqueles que lhes dão fama - desta forma, a memória do rei de Ítaca estaria preservada, sem a perigosa presença da ideia de seu não retorno. ${ }^{3}$

Contudo, por mais que deseje continuar esperando pelo marido, Penélope compreende as consequências advindas da ausência prolongada do marido, com os pretendentes esgotando os recursos do palácio e, consequentemente, a herança de Telêmaco. Não havia mais tempo para perder, uma vez que a demora da tomada sua decisão poderia custar o futuro de seu filho. Deste

\footnotetext{
${ }^{3}$ Para mais informações sobre esta passagem, cf. Werner (2018, p.97-101). 
modo, Penélope, mesmo com sua inteligência, admite não conseguir articular mais nenhum estratagema, nem vê outro meio para evitar o novo casamento.

Não obstante, o comportamento de Penélope não soa coerente ao público moderno. Se não eram poucos os sinais que indicavam a presença de Odisseu em Ítaca, por que ela decidira propor o desafio do arco para escolher o novo marido? Esta atitude poderia ser compreendida pelo público mais recente como incompatível com o resto da obra, mas o público bem sabe que, no passado, enquanto se mostrava derrotada diante os pretendentes, Penélope tramava o famoso ardil da mortalha.

A fim de despistar os pretendentes, a rainha prometeu dar início às novas bodas assim que terminasse tecer uma mortalha para seu sogro, Laerte. Todavia, o que ela tecia durante o dia, desmanchava durante a noite, processo este que conseguiu prolongar por três anos, até ser descoberta. Ou seja: se a esposa de Odisseu já havia despistado suas intenções anteriormente, o que a impediria de fazê-lo novamente? Deste modo, com seu epíteto de "bem-ajuizada"4 e sua fama de astuta e manipuladora, Penélope "[...] não surge, para nós, como figura incongruente ou esquizofrênica, mas sim como uma mulher complexa e rica” (MALTA, 2018, p.139). O leitor moderno, portanto, tende a procurar nas entrelinhas as respostas para os elementos conflitantes apresentados pelo narrador.

Com efeito, começaram a surgir leituras que atribuem à rainha maior agência no poema. Uma das mais conhecidas é a do reconhecimento precoce de Odisseu por Penélope, isto é, antes da sua revelação oficial, no canto 23. As evidências que corroboram esta teoria se encontram sobretudo no canto 19, quando o casal finalmente se encontra a sós, depois de vinte anos separados. Com Odisseu disfarçado de mendigo, é curioso notar que a Penélope se dirige a ele utilizando-se de termos como "caro" ou "sensato" (vv. 350-352), palavras incomuns para uma rainha atribuir a um mero pedinte. Além disso, o canto 19 é construído de tal modo a fazer com que o espectador espere, de fato, pela identificação de Odisseu. Afinal, segundo Sais (2011, p. 65), a qual segue o modelo de A. B. Lord, este canto segue todos os elementos de uma cena típica de reconhecimento nos moldes homéricos. A sequência formular, contudo, é interrompida quando Penélope ordena que Euricleia, sua serva, banhe o estrangeiro (vv. 357392), e é ela, então, quem reconhece Odisseu, ao perceber a inconfundível cicatriz em seu pé (vv. 392-393). Quando a serva tenta avisar Penélope, Atena desvia a atenção da rainha, impedindo-a de reconhecer o marido (vv. 476-479) e completar a esperada sequência formular. Desta maneira, é possível ler a cena de tal forma que o reconhecimento, na verdade, teria sido

\footnotetext{
${ }^{4}$ Este epíteto designado à Penélope aparece mais de 50 vezes em todo o poema.
} 
realizado pela rainha durante sua conversa com o marido, antes de pedir para que Euricleia o banhasse.

Além de explicar as variadas ironias e coincidências da narrativa, a teoria do reconhecimento precoce dá uma motivação emocionalmente plausível para a decisão de Penélope em propor do desafio do arco a fim de executar um novo casamento, mesmo após se encontrar com o mendigo-Odisseu e sonhar com bons presságios ${ }^{5}$. Afinal, tendo reconhecido Odisseu, saberia que não havia outro homem capaz de executar o desafio e, deste modo, permitiria com que a vingança de seu marido pudesse ser bem-sucedida (GRETHLEIN, 2018, p.4).

Contudo, segundo Grethlein (2018, p.12), não é incomum, na poesia homérica, que as personagens ajam somente em função do enredo, sem necessitar de uma motivação psicológica. Portanto, não seria incorreto assumir que Penélope propõe o desafio do arco simplesmente porque, sem ele, Odisseu não conseguiria dar seguimento à sua vingança. Todas as coincidências estariam apenas em função do senso de ironia do poema, muito marcante em outras passagens da obra. Quanto à quase-cena de reconhecimento, Euricleia seria tão somente a substituta de Penélope para que a cena se completasse sem estragar os planos de Odisseu (SAIS, 2011, p.72), e não seria por acaso que Atena tenha o ajudado. Mas, ainda que esta falta de motivação de Penélope soe como um defeito do poema para os leitores modernos, trata-se de um artifício típico da poesia épica, o qual provavelmente não causava incômodo aos contemporâneos de Homero.

Faz-se necessário sublinhar, entretanto, que as leituras modernas das motivações de Penélope não estão necessariamente erradas - e o próprio Grethlein $(2018$, p.14) ressalta isto. Um texto antigo não precisa continuar morto e intacto: ele pode continuar vivo e se adaptar às expectativas contemporâneas criadas pelo romance moderno, sobretudo, para uma personagem feminina que, mesmo com muito potencial narrativo, não possui um enredo próprio possivelmente por conta da misoginia, por assim dizer, inerente à cultura grega antiga .

Por último, há um outro aspecto da duplicidade de Penélope: a fidelidade da rainha. $\mathrm{O}$ poema de Homero não deixa dúvida de que a espartana, ao contrário de suas primas Clitemnestra e Helena, é uma esposa fiel. Mesmo assim, tanto Agamemnon quanto Atena recomendam que Odisseu teste sua esposa, uma vez que, na lógica misógina do mundo grego antigo, não se deve confiar nas mulheres (Od. 11.405-56). Com efeito, Penélope é

\footnotetext{
${ }^{5}$ No sonho de Penélope (vv. 535-569), vinte gansos, que viviam no palácio, são mortos por uma águia. Penélope se entristece com a morte dos animais, mas a águia a consola, dizendo que se trata, na verdade, de um excelente presságio: a águia era Odisseu e os gansos, os pretendentes: em breve, todas as aflições da rainha iriam se acabar.
} 
constantemente comparada a outras figuras femininas no imaginário da Odisseia, as quais ostentam exagerada e perigosa libido. Além disso, havia na tradição grega mais tardia, a imagem de uma luxuriosa Penélope que teria dormido com todos os pretendentes (HALL, 2008, p.191). Deste modo, pode existir um leve suspense quanto à abstinência da rainha, o qual chegaria a seu clímax no episódio do teste da cama.

No canto 23, quando Odisseu enfim revela sua verdadeira identidade à esposa, esta decide testá-lo; para tanto, pede à sua serva para que prepare o leito conjugal, mas fora do quarto - isto é, exigindo que o movesse. Isto causa grande ira ao rei de Ítaca, uma vez que a cama era originalmente fixa - para que pudessem movê-la, algum homem teria que tê-la movido, ou seja, Penélope não teria sido fiel. Aqui, portanto, insere-se o ponto máximo do suspense quanto à fidelidade da espartana: teria sido, então, Penélope infiel? Porém, é neste momento que a rainha percebe que aquele homem diante dela era, de fato, Odisseu, já que mais ninguém além do casal e da serva conhecia o segredo da cama e, portanto, só seu verdadeiro marido ficaria irritado com suas palavras. O leito permanecia inamovível e imaculado.

A cama está em paralelo com outro objeto-chave de Penélope: a mortalha. Ao contrário da cama, a particularidade da mortalha era justamente seu movimento, e, enquanto a mobilidade de um objeto representava a fidelidade, a de outro provava a traição: afinal, “quem (...) poderia ter a certeza absoluta, desde o início, de que seu dom de duplicidade contra os pretendentes no assunto do tear não poderia desta vez ser voltado contra o marido, precisamente em relação ao leito conjugal?" (ZEITLIN, 1995, p. 139) Contudo, esta é a maior habilidade de Penélope: saber utilizar de sua ambiguidade a seu favor. Ao dominar o dom de transitar entre o casamento e a viuvez, a esperança e a descrença, a mobilidade e a mobilidade, Penélope oferece ao seu público uma outra face feminina, cuja astúcia, dissimulação e mistério não são destinados à traição e destruição, mas, pelo contrário, à fidelidade e à manutenção do lar. Em outras palavras, Penélope é essencial para o retorno ao status quo, isto é, a paz que existia em Ítaca antes de Odisseu partir e que voltou a reinar com o regresso de seu rei.

Esta perspectiva é satisfatória tanto para o público antigo, o qual somente agregava valor à mulher no âmbito doméstico, quanto para o moderno, que, na busca por melhores representações femininas na literatura, consegue perceber a agência da rainha de Ítaca e seu papel fundamental para o enredo da Odisseia.

\footnotetext{
6 "Who then could be utterly certain from the start that her gift for duplicity against the suitors in the matter of the loom might not this time be turned against her husband, precisely with regard to the marital bed?"
} 


\section{SAHRAZAD}

Šahrāzād é a principal narradora do Livro das Mil e Uma Noites. Não por acaso, é um símbolo mundial de contação de histórias. Apesar de sua fama, Šahrāzād possui apenas a seguinte descrição:

Šahrāzād, a mais velha, tinha lido livros de compilações, de sabedoria e de medicina; decorara poesias e consultara as crônicas históricas; conhecia tanto os dizeres de toda gente como as palavras dos sábios e dos reis. Conhecedora das coisas, inteligente, sábia e cultivada, tinha lido e entendido. (LIVRO, 2018a, p. 52)

Ao contrário da maioria das descrições de personagens femininas que podemos encontrar na literatura mundial, nada é dito sobre a aparência física de Šahrāzād: a única característica digna de ser mencionada é a sua inteligência ${ }^{7}$. Ainda assim, sua enfática motivação - de não morrer e, por consequência, salvar outras mulheres do reino - deslumbra infinitos leitores e leitoras até hoje, sobretudo com as interpretações feministas da obra. Entretanto, embora sua motivação seja clara e sua voz dominante, Šahrāzād sofre, assim como Penélope, uma angustiante situação de liminaridade e, para livrar-se dela, utiliza-se da astúcia e da ambiguidade, como veremos a seguir.

A liminaridade de Šahrāzād começa, tal como Penélope, em sua situação marital: apesar de ser, oficialmente, esposa de Šāhriyār, seu posto não é tão concreto. A diferença entre as duas mulheres é que, enquanto Penélope lida com a possível morte do marido, Šahrāzād lida com sua própria possível morte. Este é o segundo aspecto de sua liminaridade: a sua vida. Ainda que a interação do casal seja reduzida a uma mera fórmula ao longo do livro, em teoria, existe uma inquietante tensão entre ambos e, a qualquer momento, o rei pode cansar das histórias da esposa e decidir, enfim, matá-la. Assim, a vida de Šahrāzād, durante todas as mil e uma noites, está por um fio.

A contação de histórias é proposta justamente como uma resolução da liminaridade. Ela pode ser vista de três maneiras: a primeira é como um controle do tempo, de forma a alongá-lo

\footnotetext{
7 Apesar disto, ela é constantemente associada à beleza na visão ocidental, sobretudo nas traduções. Sobre este assunto, cf. Sallis (1999, p. 101-107).
} 
o máximo possível. Ou seja, ao contar histórias, Šahrāzād estaria distraindo o rei e ganhando mais dias de vida.

Esta é, de certa forma, a técnica utilizada por Penélope para despistar seus pretendentes: fingia tecer uma mortalha para seu sogro, mas descosturava seu progresso durante a noite, de modo a nunca terminar. A resolução dos problemas da personagem homérica, entretanto, está intimamente relacionada à volta de seu marido. Penélope possui o papel fundamental de manter a memória de Odisseu intacta e manter a ordem do lar da melhor maneira possível até o retorno de seu esposo, contudo, sua liminaridade só será resolvida, de fato, junto de Odisseu.

Isto não se aplica a Šahrāzād: distrair indefinidamente o rei não é uma boa estratégia, uma vez que a personagem não está esperando ninguém para resolver sua situação - ela precisa fazê-lo sozinha. Deste modo, Šahrāzād não pode arriscar que Šāhriyār fique entediado com suas histórias, já que, se isso ocorrer, ela morrerá e a matança de mulheres continuará.

Também é preciso ter em mente que, ainda que se trate de um estratagema, a contação de histórias não é exatamente uma dissimulação, ao contrário do ardil de Penélope. A tática de Šahrāzād trata-se de uma transação - uma história espantosa em troca da sobrevivência. Este acordo é visto repetidamente ao longo do Livro das Mil e Uma Noites: a narrativa é considerada uma moeda de troca neste universo, de tal maneira que, por mais que a narradora esteja enfrentando uma situação de vida ou morte, não há motivos para crer que Šāhriyār não tenha plena consciência dos objetivos da mulher - mas decide aceitar as demandas de Šahrāzād pois

(...) o texto prometido funcionaria como um objeto causa de desejo que, furtando-se para sempre, promove o avançar da ação narrativa no deslizamento metonímico de um desejo de narrar. Mas o desejo do narrador só se arquiteta ao mancar, afinal. Sua tesão só pode se concretizar como parcialidade, fragmentação, peça miniatural. Assim, o texto adiado - vã tentativa de enlace como o objeto final de gozo - apenas se cumpre enquanto cadeia narrativa indefinidamente extensível, alusiva a um fim impossível. (WAJNBERG, 1997, p. 90)

A busca de Šāhriyār pelo gozo nos leva à segunda forma de interpretar a contação de histórias: seu poder de cura. Ora, não é difícil imaginar que narrativas - sobretudo as que dizem respeito às fábulas - sejam utilizadas como propósito educativo, ou até moralizante. Contudo, não é isto que acontece no Livro das Mil e Uma Noites: ao invés de apaziguar a sede de sangue feminino do rei, Šahrāzād parece tomar o sentido contrário, ao narrar diversas histórias sobre mulheres infiéis e perversas. Sua estratégia soa incongruente e contra produtiva, uma vez que 
alimentaria o ódio de Šāhriyār contra o sexo feminino. Todavia, a técnica da rainha não pode ser vista com tanta ingenuidade:

A recitação reiterada abrindo a narração de contos de Šahrāzād pode ser vista como indução de transe, cada vez que remete o rei ao portal de realidades ou estados alterados anteriores. Ficar em silêncio com o amanhecer então libera o rei do transe e então o elemento de lapso de tempo é curiosamente sugestivo de consciência temporal alterada sob hipnose ou meditação profunda. As imagens, sugestões e experiências acumuladas ao longo de três ou mais anos assemelham-se aos processos de cura psicológica e emocional; o que chamamos de terapia hoje (SALLIS, 1999, p.95)

Segundo a leitura proposta por Malti-Douglas (1991), Šahrāzād estaria curando o rei de sua imaturidade - sobretudo sexual - através de suas narrativas. Seu plano, porém, não dependia do caráter moralizante de seus contos, mas pelo mero prazer de ouvir uma boa história. Afinal,

[o] desejo está na raiz do prólogo-moldura das Noites, mas o desejo como um problema. Existem desejos adequados assim como desejos impróprios. Ou, para falar mais precisamente, existem padrões de desejo adequados e impróprios e maneiras de usar e satisfazer o desejo. Adequado e impróprio, aqui, são mais do que antinomias morais: eles vão além do domínio relativamente restrito do justo e do injusto para as regiões mais mundanas do apropriado e, em última análise, satisfatório (MALTI-DOUGLAS, 1991, p.15). ${ }^{9}$

Malti-Douglas (1991, p. 20) observa que Šāhriyār se relaciona com as mulheres da seguinte forma: (1) cópula; (2) morte; (3) fim da relação. Isto acontece como resultado direto da sua interação com a mulher do gênio. Ela, por sua vez, possui o seguinte padrão de relacionamento com homens: (1) ameaça de morte; (2) cópula; (3) fim da relação. Percebe-se, portanto, que "[e]la é uma mulher que explorará uma multiplicidade de homens; ele é um homem que explorará uma multiplicidade de mulheres. Em ambos os casos, os relacionamentos

\footnotetext{
8 "The reiterated recitation opening Sheherazade's tale-telling could be viewed as trance induction, each time recalling the king to the portal of earlier altered realities or states. Falling silent with the dawn then releases the king from trance and then the time lapse element is curiously suggestive of altered temporal awareness under hypnosis or deep meditation. The images, suggestions and experiences accumulated over the three or so years resemble the processes of psychological and emotional healing; what we call therapy today".

9 "Desire is at the root of the frame of the Nights, but desire as a problem. There are proper desires as there are improper ones. Or, to speak more precisely, there are proper and improper patterns of desire and ways of using and fulfilling desire. Proper and improper, here, are more than moral antinomies: they reach beyond the relatively restricted domain of the just and the unjust to the more worldly regions of the appropriate and the ultimately satisfying."
} 
são curtos e superficiais" (MALTI-DOUGLAS, 1991, p. 20). ${ }^{10}$ Os padrões de ambos são parecidos e também possuem origens semelhantes: uma eterna vingança àqueles que os traíram - o gênio que a sequestrou, no caso da moça, e a esposa que lhe foi infiel, no caso do rei. Šāhriyār, porém, estava tão absorto em sua própria dor e espanto com a audácia da jovem que nem pôde perceber que ela é mais um espelho do que uma ameaça.

Deste modo, os assassinatos provocados por Šāhriyār impedem o desenvolvimento do prazer. Sua satisfação não dura mais do que uma noite: a fonte do seu gozo precisa ser constantemente renovada. Esta conduta indica uma grande imaturidade sexual, a qual resulta em terrível caos em seu reinado, sobretudo entre as mulheres.

Šahrāzād, com sua astúcia, apresenta ao rei um novo meio de lidar com o desejo: ela manipula o tempo de modo não apenas a adiar sua morte, mas também a adiar - e, ao mesmo tempo, prolongar - o prazer. O gozo final, que nunca chega, transforma-se em um gozo prolongado, que dura mil e uma noites. À vista disto, é importante que não haja nenhuma descrição da aparência física de Šahrāzād, porque é justamente esta uma das coisas que a rainha irá desconstruir na personalidade de Šāhriyār: seu apego à visão para lhe causar prazer. A rainha oferece-lhe o gozo através da fala e da imaginação. O desejo do rei, portanto, torna-se mais refinado, aguçado e maduro. Ademais, em algumas versões da obra - incluindo a que utilizamos para este trabalho -, Šahrāzād revela sua gravidez ao marido ao final das mil e uma noites, mostrando que somente os padrões apropriados de desejo são, de fato, férteis.

A terceira maneira de interpretar o método de Šahrāzād é simplesmente seu método de convencimento. Sabemos que a contação de histórias é uma técnica de argumentação amplamente utilizada neste universo, e um dos exemplos está no próprio prólogo-moldura, quando o pai de Šahrāzād tenta convencê-la a não se casar com o rei, mas também é encontrada diversas vezes em outros momentos da obra. O método utilizado por Šahrāzād, contudo, é mais complexo do que aqueles observados no restante do texto. Geralmente, tratam-se de fábulas com uma "moral da história", isto é, a situação apresentada pelo conto facilmente se espelha na situação que a personagem narradora está vivendo e, a partir dela, expõe uma "lição a ser aprendida", um padrão moral a ser seguido. Šahrāzād, por sua vez, não é tão óbvia: suas mensagens estão escondidas nas entrelinhas. 10 "She is one woman who will exploit a multiplicity of males; he is one man who will exploit a multiplicity of
females. In both cases, relationships are short and shallow." 
Para compreender melhor, é preciso retomar a história de Šāhriyār e o motivo por de trás de seu ódio às mulheres. Quando ele e seu irmão descobrem que são traídos, Šāhriyār sugere ao irmão:

\footnotetext{
"Vamos abandonar nosso reino e perambular em amor a Deus altíssimo. Vamos desaparecer daqui. Se por acaso encontrarmos alguém cuja desgraça seja pior do que a nossa, voltaremos; caso contrário, continuaremos vagando pelo mundo, sem necessidade alguma de poder" (LIVRO, 2018a, p. 49).
}

De fato, os irmãos encontram alguém ainda mais desgraçado do que eles: um gênio, cuja esposa, mesmo presa em uma caixa, traía-o com centena de homens. Se nem um gênio, uma criatura de forças sobre-humanas, consegue escapar das traições de uma mulher, ninguém mais poderia. A própria esposa do gênio confirma tal suposição, ao dizer: “[...] quando uma mulher deseja alguma coisa, ninguém pode impedi-la" (LIVRO, 2018a, p. 51).

É interessante notar que o modo como a esposa do gênio obriga os irmãos a possui-la é muito similar ao que Šahrāzād convence seu pai a casá-la com Šāhriyār: enquanto a esposa do gênio ameaça a acordar seu marido (que, inevitavelmente, irá matá-los) se seu desejo não for satisfeito, Šahrāzād ameaça a contar ao rei que seu pai lhe negou a mão de sua filha, ato que resultaria na morte do vizir. Esta semelhança entre as duas personagens atribui um aspecto perigoso à Šahrāzād: ela, enquanto mulher - assim como a esposa do gênio, - não poderá ser impedida de ter o que deseja. E Šahrāzād tem um objetivo muito claro: a salvação das mulheres.

A esposa do gênio alcança seu objetivo através da sua autoridade, obtida por meio do seu marido: os irmãos a obedecem pois temem que ela acorde o gênio. De certa forma, mesmo sendo uma mulher humana, a jovem possui um grande poder, atribuído pelo gênio (de forma consciente ou não) ao se casar com ela. De maneira parecida, Šahrāzād atinge seus objetivos: ela pede a Šăhriyār a autoridade, o qual concede quando lhe permite que conte suas histórias:

Šahrāzād obtém o privilégio de narrar, anulando assim sua relação com seu mestre. As histórias de Sahrāzād são contos que hipnotizam o rei. Como narradora, ela tem a vantagem ao reivindicar o papel de ditadora. [...] O ouvinte, por definição, é aquele que recebe informações, ou seja, a parte passiva no ato da narração. Assim, a posição de Šahrāzād é oposta à convencional, onde a fala é o direito do dominante; a qual deveria ser do rei Šāhriyār. Depois de pedir sua permissão para começar suas histórias, ela se dirige a ele, ou melhor, o ordena dizendo: "Ouça" (EL-NAGGAR, 2017, p. $24)^{11}$.

\footnotetext{
11 "Shahrazad obtains the privilege of narrating, thus overturning her relationship with her master. Shahrazad's
} stories are tales that mesmerize the king. As the narrator, she has the upper hand claiming the role of the dictator. 
Apesar de ter a voz dominante, Šahrāzād não ultrapassa seu papel: sua fala sempre está condicionada à permissão do rei. Nota-se que o rei não pede pelas histórias, apesar de ter sido fisgado por elas: este papel cabe à Dīnāzārd. Šahrāzād, portanto, por meio de seu plano, coloca Šāhriyār em uma condição passiva sem que ele perca seu poder, ajudando, provavelmente, a apaziguar sua cólera.

Uma característica importante a ser destacada nas Noites é que, nesta obra, um personagem pode ser bidimensional e complexo, ao mesmo tempo: "A complexidade do personagem é alcançada por meio da repetição, sombras, duplicação, colagem e referência indireta" (SALLIS, 1999, p. 96): ${ }^{12}$. Assim, o espelhamento é essencial tanto para que o público possa compreender Šāhriyār, quanto para que o próprio rei possa se compreender ao ouvir os contos da esposa. Na primeira noite, Šahrāzād narra a história de um mercador que, ao jogar as sementes de suas tâmaras no chão, sem perceber, acaba matando o filho de um poderoso gênio, o qual se vê na obrigação de matar o assassino de seu herdeiro. As semelhanças com o prólogomoldura são claras: ainda que a vingança do gênio venha de uma dor verdadeira, não deixa de ser injusta, tal qual a vingança de Šāhriyār. A rainha encerra a narrativa na emblemática cena em que o gênio desembainha sua espada e está prestes a matar o mercador - assim como a própria Šahrāzād está prestes a morrer nas mãos do rei e a possível misericórdia do gênio só poderá existir se Šāhriyār também for misericordioso.

Assim acontece: Šāhriyār cede mais uma noite de vida para Šahrāzād, em troca da continuação da narrativa - do mesmo modo, o gênio concede a vida do mercador a outros três xeiques que por ali estavam de passagem, em troca de boas histórias. As narrativas dos xeiques, por sua vez, contam com mulheres perversas ameaçando os homens protagonistas, mas cujas armadilhas e feitiçarias são desmanchadas pelas mãos de outras mulheres, com as quais os protagonistas se casam (cf. SHAMMA, 2017). Este tema é constantemente retomado ao longo das histórias das Noites.

Desta maneira, na última noite, Šāhriyār pensa consigo: "Se com os califas e os reis sassânidas ocorreu pior do que ocorreu comigo, vou parar de me autocensurar” (LIVRO, 2018d, p. 490). Estas palavras não parecem vir de um homem que se convenceu de que mulheres são

[...] The listener, by definition is one who receives information, that is, the passive party in the act of narration. Accordingly, Shahrazad's position is the opposite of the conventional one, where speech is the right of the dominant; who should be King Shahrayar. After taking his permission to start her stories, she addresses him or rather orders him saying: 'Listen'".

12 "Complexity of character is achieved through repetition, shadows, duplication, collage and indirect referral." 
seres confiáveis, mas simplesmente de alguém que entendeu que elas podem ser piores do que pensava - ou, no mínimo, compreendeu que mulheres são plurais e existem um grande espectro variando da maldade à bondade entre elas. Assim, se não aconteceu o pior com ele, não há motivo para ter tanto ódio e tomar medidas tão drásticas. Acima de tudo, o rei percebe a importância das mulheres na vida dos homens - deste modo, admite sua sorte em encontrar Šahrāzād, uma mulher diferente das outras, com quem pode manter um casamento funcional e fértil.

Desta forma, Šahrāzād é construída tanto como uma mulher pacífica, com o objetivo de curar, quanto como alguém pérfido, o objetivo de amedrontar. Sua posição é tanto ativa quanto passiva, tanto dominante quanto dominada, tanto curadora quanto assustadora. Todas as facetas de Šahrāzād coexistem e compõem uma personagem complexa e rica, a qual agrega discussões valiosas até os dias atuais, promovendo em seus leitores a mesma cura e assombro que provocou em Šāhriyār.

\section{CONSIDERAÇÕES FINAIS}

Como já atestado anteriormente, a Odisseia e o Livro das Mil e Uma Noites são obras bastante distintas entre si. Não apenas foram concebidas em épocas muito diferentes, em gêneros diferentes, e culturas diferentes: o enredo também segue direções totalmente díspares. Além disto, os poemas homéricos só foram traduzidos para o árabe no século XX (GRAZIOZI; GREENWOOD, 2007, p.1), muito tempo depois da concepção das Noites. Contudo, ainda que a troca cultural tenha sido difícil, não era impossível: muitos árabes sabiam grego e tinham conhecimento das obras de Homero (IRWIN, 2004, p. 71). Ademais, nada impede que os mitos gregos tenham atravessado as fronteiras através de outras fontes - sobretudo orais -, de modo a adentrar no imaginário árabe. Isto pode ser verificado na terceira viagem de Sindabād, cujo enredo é praticamente idêntico ao episódio de Polifemo, na Odisseia (IRWIN, 2004, p. 71): tanto Odisseu quanto Sindabād, junto a suas respectivas tripulações, desembarcam em uma ilha de gigantes, são capturados por um deles e, para escaparem, atingem uma estaca em seu olho.

Deste modo, comparar a Odisseia e as Noites não é de todo incoerente, a tal ponto que o próprio Galland (o primeiro tradutor das Noites para uma língua europeia) chegou a fazer algumas conexões entre ambas, como a semelhança entre Circe e a rainha Lāb - do conto Jullānar, a maritima, e seu filho Badr - enquanto mulheres sensuais e perversas que transformam homens em animais (IRWIN, 2004, p. 71). Contudo, é possível notar uma relação 
intertextual para além de personagens ou situações específicas: ambas apresentam temas em comum - no caso, o tema do espaço das mulheres na sociedade e, acima disso, a relação entre homens e mulheres no patriarcado.

Ainda que esta não seja uma questão central na obra homérica, a presença feminina no poema é notável. Como já foi discutido anteriormente, as mulheres da Odisseia se destacam por serem mais misteriosas, ambíguas e, de certa forma, complexas. Elas representam um perigo aos homens, assim como os monstros e outras criaturas míticas. Assim, diante desta ameaça, a Odisseia sutilmente traz a pergunta: "como lidar com a ameaça que as mulheres oferecem?”. Já no Livro das Mil e Uma Noites, o tópico não é nada sutil - pelo contrário, é o fio que conduz o enredo: Šāhriyār não apenas se pergunta como lidar com a ameaça feminina, como já tem a resposta: o feminicídio.

Neste contexto, surgem as personagens Penélope e Šahrāzād: ambas expõem o conceito da mulher virtuosa e fiel, em contraste àquelas perversas, libidinosas, incontroláveis e traidoras. Não é incomum a imagem da mulher enquanto símbolo de perigo: no Ocidente, encontramos exemplos canônicos como Eva (da Bíblia) e Pandora (da Teogonia de Hesíodo). Ambas são as primeiras mulheres existentes na Terra de acordo com seus respectivos mitos de criação, e ambas são responsáveis por trazerem o Mal à humanidade. Deste modo, é compreensível que as heroínas do Livro das Mil e Uma Noites e da Odisseia sejam muitas vezes vistas como símbolos feministas, uma vez que desafiam a misoginia e se provam capazes de astúcia e agência. Entretanto, neste trabalho, procuramos demonstrar que esta visão pode ser anacrônica e um tanto equivocada: Penélope e Šahrāzād não tinham nenhum outro objetivo senão o retorno à ordem original do patriarcado.

Com a ausência do patriarca, isto é, Odisseu, seu palácio em Ítaca estava mergulhado no caos. Sem um líder, o lar de Odisseu estava tomado por centenas de pretendentes odiosos, que oprimiam seus familiares e servos fiéis, além de usurparem suas riquezas. Já no universo das Noites, ainda que o patriarca estivesse presente, sua decisão de matar mulheres aterrorizava a população e estabelecia o caos: além do desespero das virgens, que temiam por suas vidas, e de seus parentes que as amavam, existia também a agonia jovens homens que se viam com cada vez menos opções de casamento. Portanto, se os patriarcas destas obras não conseguiam trazer a ordem, cabia às mulheres esta função.

É importante salientar que a mulher, por mais inferiorizada que seja pelo patriarcado, exerce papéis fundamentais para a manutenção deste e, sem ela, o sistema entra em colapso. Da mesma forma, sem um homem, não há ordem. Assim, ambos precisam estar atentos para manter o patriarcado intacto e, caso a estabilidade seja ameaçada - ou até mesmo destruída -, eles 
precisam agir. Contudo, sua agência não pode ultrapassar os limites do seu gênero, ou seja, as mulheres não podem ser autoritárias, muito menos ultrapassar a autoridade do patriarca.

A situação, portanto, é complexa e exige astúcia, além da inevitável ambiguidade: afinal, é impossível ser autoritária e não autoritária ao mesmo tempo sem ser ambígua. A solução de Penélope foi o estratagema da mortalha: enquanto se mostrava aos pretendentes como uma mulher chorosa que aceitava sua viuvez e costurava uma mortalha ao sogro, desmanchava o tecido à noite, ganhando tempo para o retorno de seu marido. Penélope escolheu o silêncio e, por meio dele, é difícil até mesmo para o público desvendar suas verdadeiras intenções. O estratagema da rainha de Ítaca, porém, conta com o eventual retorno do marido ao lar, afim de vingar-se. Deste modo, Penélope reconhece seu papel e, acima de tudo, o papel de Odisseu e sua autoridade.

Já Šahrāzād, ao contrário de Penélope, escolhe a voz. Mesmo assim, também não fica totalmente claro ao público quais são suas verdadeiras intenções - se quer ganhar tempo, curar ou assustar o rei. Seja como for, sabemos que quer acabar com a matança de mulheres - e é o que consegue. Mas em momento algum ultrapassa a autoridade do rei: ela, por mais que seja a narradora por excelência, só inicia as narrativas com a permissão do marido. Sem a concessão de Šāhriyār, Šahrāzād nada faz e nem pode fazer: seu plano conta com o respeito da posição do rei enquanto patriarca.

Se Šāhriyār ou Odisseu não retomassem seu devido lugar de direito no patriarcado, a ordem não voltaria a ser estabelecida de fato. O objetivo de Penélope e Šahrāzād não é a revolução - muito menos uma revolução feminista - mas a paz, que antevê um sistema patriarcal em equilíbrio. Portanto, a mulher virtuosa, isto é, a mulher fiel e confiável é aquela que sabe manter o status quo e exercer os papéis exigidos do seu gênero.

Com este trabalho, não pretendemos desconsiderar as leituras feministas das obras em questão, as quais, por mais que sejam anacrônicas, possuem sua devida relevância. Nosso objetivo foi de reunir as semelhanças entre as Noites e a Odisseia enquanto duas obras que se referem às relações entre homens e mulheres e evidenciar as impressões patriarcais que emergem nas figuras de suas heroínas. Assim, conclui-se que, ainda que as duas obras possam não ter referências diretas, há semelhanças consideráveis, as quais expõem comportamentos sociais e culturais que se repetem em épocas tão distantes entre si.

\section{Referências Bibliográficas}


CANEVARO, L. G. Women of substance in Homeric epic. Oxford: Oxford University Press, 2018.

EL-NAGGAR, N. Exploring the Frame Story in The Arabian Nights Gender and the Question of Authority. International Journal of Social Science and Business, vol. 2, n. 1, p. 19-28, 2017.

FOWLER, D. On the Shoulders of Giants: Intertextuality and Classical Studies. Materiali e Discussioni Per L'analisi Dei Testi Classici, n. 39, p. 13-34, 1997.

GLENN, J. Pandora and Eve: sex as the root of all evil. The Classical World, vol. 71, no. 3, p. 179-185, 1977.

GRAZIOSI, B.; GREENWOOD, E. (Org.). Homer in the twentieth century: between world literature and the western canon. Oxford: Oxford University Press, 2007.

GRETHLEIN, J. Homeric motivation and modern narratology: the case of Penelope. Cambridge Classical Journal, n. 64, 2018, p. 1-21.

GRUNEBAUM, G. Greek form elements in the Arabian Nights. Journal of the American Oriental Society, vol. 62, n. 4, p. 277-292, 1942.

HALL, E. The Return Of Ulysses: a cultural history of Homer's Odyssey. London/New York: I. B. Tauris, 2008.

HOMERO. Ilíada. Trad: C. Werner. São Paulo: Ubu, 2018.

HOMERO. Odisseia. Trad: C. Werner. São Paulo: Cosac Naify, 2014.

IRWIN, R. The Arabian Nights: a companion. New York/London: Tauris Parke Paperbacks, 2004.

LIVRO das Mil e Uma Noites. Tradução: Mamede Mustafá Jarouche. São Paulo: Biblioteca Azul, 2018a (v.1), 2018b (v.2), 2018c (v.3), 2018d (v.4). 
MALTA, A. A astúcia de ninguém: ser e não ser na Odisseia. Belo Horizonte: Impressões de Minas, 2018.

MALTI-DOUGLAS, F. Woman's body, woman's word: gender and discourse in Arabo-islamic writing. Princeton: Princeton University Press, 1991.

XXX. Recepção dos clássicos em Machado de Assis: ecos homéricos de Helena e Penélope na caracterização de Capitu. Nuntius Antiquus, v. 16, n. 2, p. 87-110, 2020.

SAIS, L. A. Odisseia XIX: Penélope Anfitriã. Letras Clássicas, n. 15, p. 62-77, 2011.

SALLIS, E. Sheherazade through the Looking Glass: The Metamorphosis of the Thousand and One Nights. New York: Routledge, 1999.

SHAMMA, T. Women and slaves: gender politics in The Arabian Nights. Marvels \& Tales, vol. 31, n. 2, p. 239-260, 2017.

WAJNBERG, D. Jardim de Arabescos: uma leitura das Mil e Uma Noites. Rio de Janeiro: Imago, 1997.

WERNER, C. A ambiguidade do kléos na Odisseia. Letras Clássicas, n. 5, p. 99-108, 2001.

WERNER, C. Introdução. In: HOMERO. Odisseia. Trad: C. Werner. São Paulo: Cosac Naify, 2014, p. 59-93.

WERNER, C. Memórias da Guerra de Troia: a performance do passado épico na Odisseia de Homero. Coimbra / São Paulo: Imprensa da Universidade de Coimbra / Annablume, 2018.

ZEITLIN, F. Figuring fidelity in Homer's Odyssey. In: COHEN, B. (org.) Distaff side: representing the female in Homer's Odyssey. Oxford: Oxford University Press, 1995, p. 117152. 